\title{
The Purpose of Rhetoric in Late Antiquity
}

\author{
From Performance to Exegesis \\ Ed. by Alberto J. Quiroga Puertas
}

[Der Gebrauch von Rhetorik in der Spätantike. Vom Vollzug zur Exegese.]

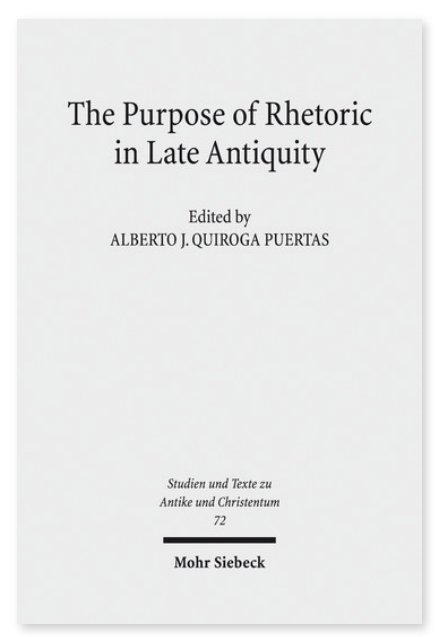

2013. XI, 265 Seiten. STAC 72

ISBN 978-3-16-152352-6

DOI 10.1628/978-3-16-152352-6

eBook PDF 79,00€

ISBN 978-3-16-152269-7

fadengeheftete Broschur 79,00€
Veröffentlicht auf Englisch.

In diesem Band versammelt Alberto J. Quiroga Puertas zwölf Aufsätze, die sich mit der Rolle und der Bedeutung der Rhetorik in Theologie, Literatur und Politik in der Spätantike, genauer im 4. Jahrhundert n. Chr., befassen. Ausgangspunkt der Untersuchungen ist die Annahme, dass religiöse, kulturelle und politische Diskussionen zu dieser Zeit auf dem Schauplatz der Rhetorik ausgefochten wurden. Demzufolge werden in diesem Band Aspekte diskutiert, die in Beziehung zur religiösen Orthodoxie und der Verurteilung der Ketzerei, zur spirituellen Weiterentwicklung, zur Gestaltung eines literarischen Werks oder zu den ideologischen Grundsätzen der rhetorischen Bildung in der Spätantike stehen. Autoren wie Themistios, Libanios, Augustinus, Evagrius, Firmicus oder Kaiser Julian nutzten in ihren Werken rhetorische Hilfsmittel und Strategien, um ihre Argumente zu bekräftigen. Das leicht veränderliche Wesen der Rhetorik förderte ihre Verwendung mit variablem Zweck: Sie konnte sowohl der Hermeneutik als auch der Überzeugungskunst oder der Exegese dienen.

\section{Inhaltsübersicht}

Alberto J. Quiroga Puertas: Foreword

1. Words and the Word: Rhetorical Strategies and Theology

Philip Rousseau: Homily and Exegesis in the Patristic Age: Comparisons of Purpose and Effect - Nicholas Baker-Brian: Between Testimony and Rumour: Strategies of Invective in Augustine's De moribus manichaeorum - Ilaria Ramelli: A Rhetorical Device in Evagrius: Allegory, the Bible, and Apokatastasis - Josef Lössl: Profaning and Proscribing. Escalating Rhetorical Violence in Fourth Century Christian Apologetic

2. Sacred and Profane in Late Antique Literature

Laura Miguélez: Rhetoric for a Christian Community: The Poems of the Codex Visionum - Manfred Kraus: Rhetoric or Law? The Role of Law in Late Ancient Greek Rhetorical Exercises - Aglae Pizzone: When Calasiris Got Pregnant: Shifting Perspectives on Story-Telling in Heliodorus' Aethiopica - John Watt: Themistius and Julian: their Association in Syriac and Arabic Tradition 3. Rhetoric and Political Speeches

David Konstan: Themistius on Royal Beauty - Guadalupe Lopetegui: The Panegyrici Latini: Rhetoric in the Service of Imperial Ideology - Peter Van Nuffelen/Lieve Van Hoof: No Stories for Old Men. Damophilus of Bithynia and Plutarch in Julian's Misopogon - Alberto J. Quiroga Puertas: Libanius' Horror Silentii Robert Penella: Prologue

Alberto J. Quiroga Puertas Keine aktuellen Daten verfügbar.

Jetzt bestellen:

https://mohrsiebeck.com/buch/the-purpose-of-rhetoric-in-late-antiquity-9783161523526?no_cache=1

order@mohrsiebeck.com

Telefon: +49 (0)7071-923-17

Telefax: +49 (0)7071-51104 